\section{Follicular (Estrus) Hormone and Plant Tumours}

A FEw years ago $I$ observed that female rats and mice, given subcutaneous injections of a watery suspension of $B$. tumefaciens, or subcutaneous implantations of the crown gall tumours of pelargoniums, appeared to reach sexual maturity before control animals did. Harde ${ }^{1}$, Yano ${ }^{2}$, Dodds ${ }^{3}$, and others, have given experimental proof of the possibility of a carcinogenic sensitisation of animals through administration of sexual-especially the follicularhormones.

In previous experiments ${ }^{4}$ it was clearly shown that the œstrus hormone had marked effects upon certain plants, and it was also observed that, when introduced in toxic doses through a petiolar stump into tomato plants, this hormone manifested its effects upwards along the stem, above the point of introduction.

In the present experiments, a similar introduction of an acqueous solution of a hormone was made into tomato plants, which were afterwards inoculated above and below the petiole with $B$. tumefaciens. Commercial crystalline œstrus hormones ('Glandubolin' of Richter, and 'Hogival' of Chinoin), prepared from urine of pregnant mares, were used; the average total dose absorbed was $434 \cdot 3$ mouse units per plant during the period June 8-21, 1935. In spite of the high dosage, toxic effects were almost negligible in comparison with those seen on tomato plants similarly treated in winter ${ }^{4}$.

Thirty-one plants were treated with hormone, and a similar number served as controls; all were inoculated with $B$. tumefaciens, but twenty-one received distilled water, and ten received a deproteinised, hormone-free extract of animal tissuein all cases via the petioles.

At the first sign of necrosis of the tumours they were cut off and weighed. The average weights of the tumours per plant were as follows:

\begin{tabular}{ccc} 
Treatment & \multicolumn{2}{c}{$\begin{array}{c}\text { Position of tumours in relation } \\
\text { to petiolar stump }\end{array}$} \\
& Above & Below \\
& & \\
Estrus hormone & $0.554 \mathrm{gm}$. & $0.303 \mathrm{gm}$. \\
$\begin{array}{c}\text { Controls : } \\
\text { Distilled water } \\
\text { Special extract }\end{array}$ & $0.452 \mathrm{gm}$. & $0.427 \mathrm{gm}$. \\
& $0.407 \mathrm{gm}$. & $0.423 \mathrm{gm}$.
\end{tabular}

These results indicate that though the weights of the tumours on the control plants were not significantly a function of their position, the mean weight of the uppermost tumours on the plants treated with ostrus hormone was about 80 per cent greater than the mean weight of tumours below the petiole.

The final interpretation of these observations must depend upon further work to decide whether the direction of migration of the hormone in the plant is constant, or whether it is different with physiological and toxic doses.

\section{László Havas.}

Hungarian Biological Research Institute, Tihany,

Hungary.

Sept. 3.

${ }^{1}$ Harde, E., C.R. Soc. Biol. Paris, 116, 999 ; 1934

" Yano, J., Acta Dermat. Kyoto, 28, 20; 1934.

'Dodds, E. C., Vehr. l. Intern. Kongr. Kampf Krebs, 2, 181 ; 1933.

- Havas, L., and Caldwell, J., Ann. Bot., in the press.

\section{Effect of Vitamin C (Ascorbic Acid) on the Growth of Plants}

THE effect of vitamin C on plants was studied with sterile plant cultures. $40 \mathrm{mgm}$. of crystalline ascorbic acid was added to the liquid medium. It was found that the dry weight of the treated plants was about 35-75 per cent higher than that of the controls. The differences were greatest during flowering. The treated plants also showed a much higher content of vitamin C, particularly at the early stages. These results are illustrated by the table below. It is pointed out that the observed increase of growth is specifically due to ascorbic acid, and not merely to an addition of organic material to the inorganic medium, since a similar addition of glucose effected no increase in the growth of the plants.

'Torstai'-peas in sterile Hiltner's solution $\left(\mathrm{Ca}\left(\mathrm{NO}_{3}\right)_{2}\right)$; initial $p \mathrm{H} \quad 5 \cdot 5$.

\begin{tabular}{|c|c|c|c|c|c|c|}
\hline \multirow[t]{2}{*}{$\begin{array}{l}\text { Time of } \\
\text { growth, } \\
\text { in days }\end{array}$} & \multirow[t]{2}{*}{ Stage of growth } & \multicolumn{2}{|c|}{$\begin{array}{l}\text { Dry weight of } 2 \\
\text { plants, in grams }\end{array}$} & \multirow{2}{*}{$\begin{array}{l}\text { Increase } \\
\text { of crop } \\
\text { per } \\
\text { cent }\end{array}$} & \multicolumn{2}{|c|}{$\begin{array}{l}\text { Vitamin Cper } 1 \mathrm{gm} \text {. } \\
\text { dry matter } \\
\text { (ml. of indicator } \\
\text { solution) }\end{array}$} \\
\hline & & Treated & Controls & & Treated & Controls \\
\hline $\begin{array}{l}20 \\
23 \\
29 \\
34 \\
39 \\
44 \\
47 \\
50 \\
52 \\
55\end{array}$ & $\begin{array}{l}\text { Before flowering } \\
\text { ", ", } \\
\text { Stärt of flowering } \\
\text { Full bloom } \\
\text { Small pods } \\
\text { Full pods } \\
\text { ", ", } \\
\text { ", ", }\end{array}$ & $\begin{array}{l}1 \cdot 774 \\
2 \cdot 204 \\
2 \cdot 682 \\
4 \cdot 641 \\
5 \cdot 692 \\
6 \cdot 647 \\
7 \cdot 119 \\
7 \cdot 906 \\
8 \cdot 122 \\
8 \cdot 423\end{array}$ & $\begin{array}{l}1 \cdot 261 \\
1 \cdot 652 \\
1 \cdot 851 \\
2 \cdot 666 \\
3 \cdot 835 \\
4 \cdot 794 \\
4 \cdot 343 \\
5 \cdot 550 \\
5 \cdot 820 \\
6 \cdot 117\end{array}$ & $\begin{array}{l}40 \cdot 7 \\
33 \cdot 4 \\
44 \cdot 9 \\
74 \cdot 1 \\
48 \cdot 4 \\
38 \cdot 7 \\
63 \cdot 9 \\
42 \cdot 5 \\
39 \cdot 6 \\
37 \cdot 7\end{array}$ & $\begin{array}{l}44 \\
40 \\
37 \\
35 \\
36 \\
32 \\
25 \\
24 \\
23 \\
21\end{array}$ & $\begin{array}{l}20 \\
19 \\
22 \\
24 \\
30 \\
29 \\
26 \\
25 \\
24 \\
24\end{array}$ \\
\hline
\end{tabular}

Note added to proof. With regard to a communication by László Havas in Nature of September 14, p. 435 , concerning the effect of ascorbic acid on the growth of seedlings, I wish to point out that a report by me on the effect of vitamin $\mathrm{C}$ on plant growth ${ }^{1}$ was published on May 8, 1935. Mr. László Havas has apparently not known of this earlier paper.

Synnöve v. HaUsen.

Laboratory of the Foundation for Chemical Research, Helsinki. Aug. 30.

${ }^{1}$ Synnöve v. Hausen, Suomen Kemistilehti B, 5-6; 1935.

\section{Mycorrhizal Habit in the Genus Citrus}

IN a communication to NATURE, written when visiting the Citrus Experimental Station, University of California, I directed attention to the mycorrhizal habit in species of Citrus used as stocks for orange in Southern California, and to the possible relation of this habit with observed inconsistencies of response to the application of nitrogenous fertilisers ${ }^{1}$. The matter is one of considerable practical interest in view of the prevalent use of such fertilisers and the heavy cost of manuring in Californian orchards.

An investigation followed, the recently published results ${ }^{2}$ of which justify the views expressed in my original note. Intensive study of the cytological changes in the roots of plants from experimental plots receiving different manurial treatments leads the authors to emphasise "the importance of the mycorrhizal association as a factor in the metabolism of Citrus root cells", and to conclude that: "the relations between the root cell and the endophytic fungus contribute to an understanding of the responses 